\title{
Multiple Sclerosis Relapse Presenting as Sensorineural Hearing Loss
}

Parth Bansal, MD, Birinder S. Paul, DM, and Gagandeep Singh, DM, FAMS, FRCP

Neurology ${ }^{\circledR}$ 2021;96:767-768. doi:10.1212/WNL.0000000000011796

Figure Multiple Images of MRI Brain Soon After Relapse Onset

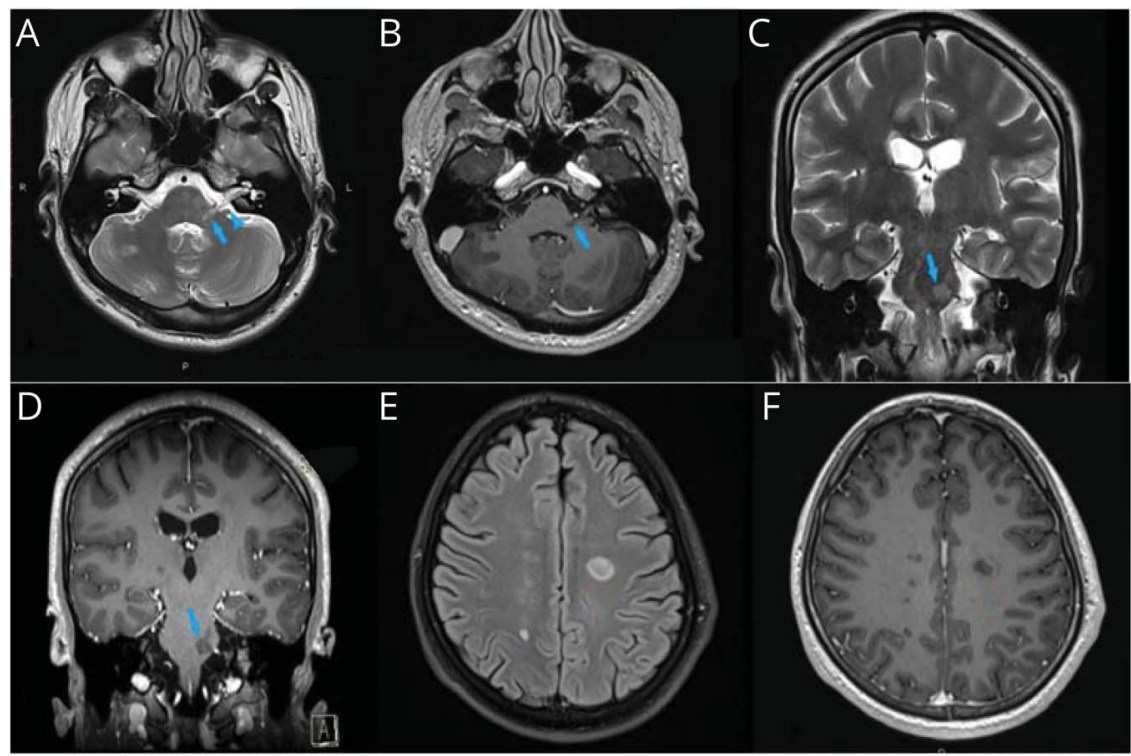

Axial T2 (A) and T1 postcontrast (B) images show the plaque in the left paramedian pons (arrow) with extension to root of the VIIIth cranial nerve (arrowhead); (C) T2 and (D) T1 postcontrast coronal images of the same lesion; and axial T2 fluid-attenuated inversion recovery (E) and T1 postcontrast (F) images at a supraventricular level.

A 23-year-old patient with multiple sclerosis on dimethyl fumarate presented with new-onset left-sided hearing loss, vertigo, and tinnitus. ${ }^{1}$ Prior to presentation, serial imaging showed no new or active lesions.

Rinne test was positive bilaterally and Weber test was lateralized to the right side. The remainder of the neurologic examination was normal. ENT workup excluded other causes of deafness. Contrast MRI brain revealed an active demyelinating plaque in the left paramedian pons extending to the root entry zone of the left vestibulocochlear nerve (figure). This differs from previously reported cases because there is evidence of involvement of the VIIIth nerve fascicle rather than the nerve. ${ }^{2}$

\section{Study Funding}

No targeted funding reported.

\section{Disclosure}

The authors report no disclosures relevant to the manuscript. Go to Neurology.org/N for full disclosures.

From the Department of Neurology, Dayanand Medical College and Hospital, Ludhiana, Punjab, India.

Go to Neurology.org/N for full disclosures. 
Appendix Authors

\begin{tabular}{lll}
\hline Name & Location & Contribution \\
\hline $\begin{array}{l}\text { Parth Bansal, } \\
\text { MD }\end{array}$ & $\begin{array}{l}\text { Dayanand Medical } \\
\text { College and Hospital, } \\
\text { Ludhiana, India }\end{array}$ & $\begin{array}{l}\text { Designed and } \\
\text { conceptualized study, } \\
\text { analyzed the data, } \\
\text { drafted the manuscript for } \\
\text { intellectual } \\
\text { content }\end{array}$ \\
\hline $\begin{array}{l}\text { Birinder S. } \\
\text { Paul, DM }\end{array}$ & $\begin{array}{l}\text { Dayanand Medical } \\
\text { College and Hospital, } \\
\text { Ludhiana, India }\end{array}$ & Supervised workup \\
\hline
\end{tabular}

Appendix (continued)

\begin{tabular}{lll}
\hline Name & Location & Contribution \\
\hline $\begin{array}{ll}\text { Gagandeep } \\
\text { Singh, DM, }\end{array}$ & $\begin{array}{l}\text { Dayanand Medical } \\
\text { CAMS, FRCP }\end{array}$ & $\begin{array}{l}\text { Designed and conceptualized } \\
\text { Ludhiana, India }\end{array}$ \\
\hline
\end{tabular}

\section{References}

1. Thompson AJ, Banwell BL, Barkhof F, et al. Diagnosis of multiple sclerosis: 2017 revisions of the McDonald criteria. Lancet Neurol. 2018;17:162-173.

2. Bergamaschi R, Romani A, Zappoli F, Versino M, Cosi V. MRI and brainstem auditory evoked potential evidence of eighth cranial nerve involvement in multiple sclerosis. Neurology. 1997;48:270-272.

\section{COVID-19 and Neurologic Disease: Call for Papers!}

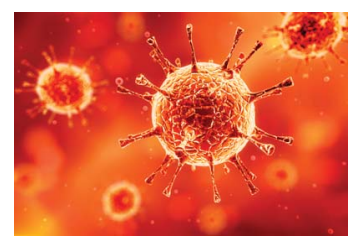

The editors of Neurology are interested in papers that address the neurological aspects of COVID-19 infection and challenges to the management of patients with chronic neurological conditions who have, or are at risk for, the infection. Relevant papers that pass initial internal review will undergo expedited peer review and online publication. We will consider papers posted in preprint servers.

Submit observational studies and clinical trials as Articles and case series and case reports under the Clinical/Scientific Notes category to https://submit.neurology.org/ today!

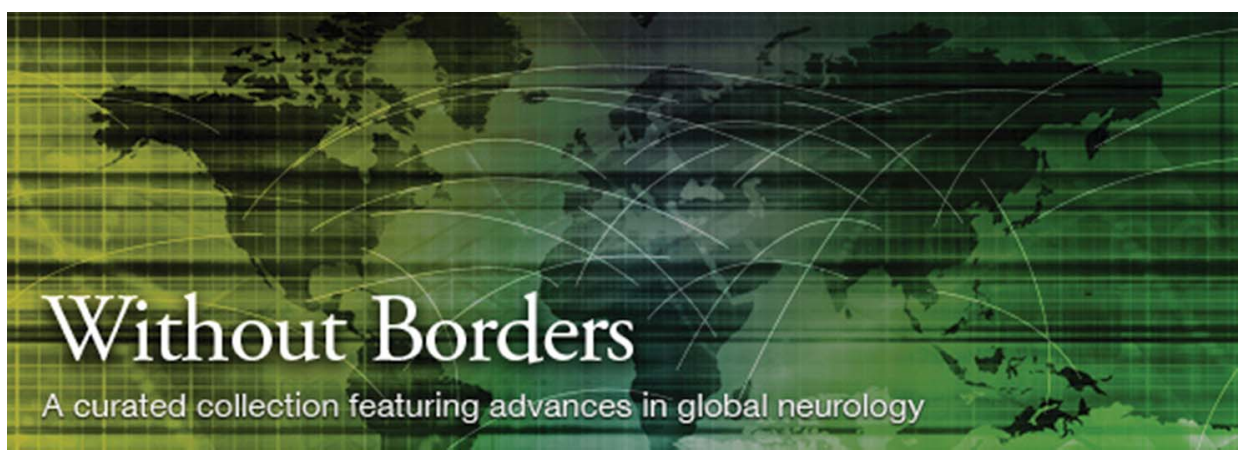

\section{Without Borders - A curated collection featuring advances in global neurology}

This Neurology ${ }^{\circledR}$ special interest website is the go-to source for tracking science and politics of neurology beyond the United States, featuring up-to-the-minute blogs, scholarly perspectives, and academic review of developments and research from Neurology journals and other sources. Curated by Gretchen L. Birbeck, MD, MPH.

Expand your world view at Neurology.org/woborders. 


\section{Neurology}

\section{Multiple Sclerosis Relapse Presenting as Sensorineural Hearing Loss}

Parth Bansal, Birinder S. Paul and Gagandeep Singh

Neurology 2021;96;767-768 Published Online before print March 2, 2021

DOI 10.1212/WNL.0000000000011796

This information is current as of March 2, 2021

$\begin{array}{ll}\begin{array}{l}\text { Updated Information \& } \\ \text { Services }\end{array} & \begin{array}{l}\text { including high resolution figures, can be found at: } \\ \text { http://n.neurology.org/content/96/16/767.full }\end{array} \\ \text { References } & \text { This article cites } 2 \text { articles, } 1 \text { of which you can access for free at: } \\ & \text { http://n.neurology.org/content/96/16/767.full\#ref-list-1 } \\ \text { Subspecialty Collections } & \text { This article, along with others on similar topics, appears in the } \\ & \text { following collection(s): } \\ & \text { All Demyelinating disease (CNS) } \\ & \text { http://n.neurology.org/cgi/collection/all_demyelinating_disease_cns } \\ & \text { MRI } \\ \text { http://n.neurology.org/cgi/collection/mri } & \text { Multiple sclerosis } \\ & \text { http://n.neurology.org/cgi/collection/multiple_sclerosis } \\ & \text { Information about reproducing this article in parts (figures,tables) or in } \\ & \text { its entirety can be found online at: } \\ \text { http://www.neurology.org/about/about_the_journal\#permissions } & \text { Information about ordering reprints can be found online: } \\ \text { Permissions \& Licensing } & \text { http://n.neurology.org/subscribers/advertise }\end{array}$

Neurology ${ }^{\circledR}$ is the official journal of the American Academy of Neurology. Published continuously since 1951, it is now a weekly with 48 issues per year. Copyright @ 2021 American Academy of Neurology. All rights reserved. Print ISSN: 0028-3878. Online ISSN: 1526-632X.

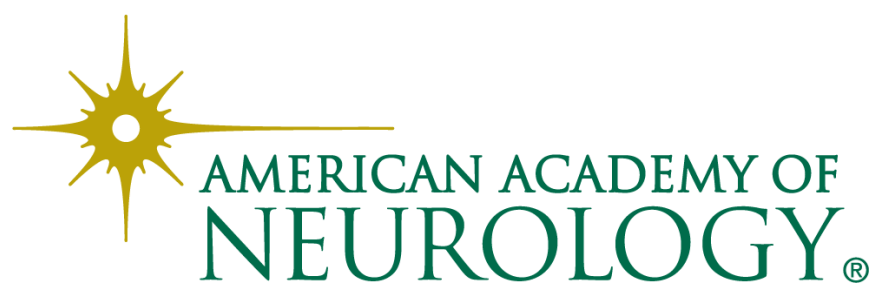

